\title{
CICHO SIĘ KRĘCI POWIELACZ
}

\section{JAN OLASZEK, REWOLUCJA POWIELACZY. NIEZALEŻNY RUCH WYDAWNICZY W POLSCE 1976-1989}

\author{
Lukasz Bertram \\ Uniwersytet Warszawski
}

Doświadczenie drugiego obiegu wydawniczego w PRL - czyli wydawania, drukowania i kolportowania książek oraz prasy poza zasięgiem państwowej cenzury - powróciło niedawno do sfery publicznej za sprawa książki Jacka Hugo-Badera Skucha (2016). Ten wyrazisty obraz prężnego w latach 80. środowiska drukarzy, kolporterów i redaktorów Międzyzakładowego Komitetu Koordynacyjnego oraz pisma „Wola” przefiltrowany jest jednak przez osobisto-reporterską wrażliwość. Spojrzenie na historię drugiego obiegu wydawniczego w bardziej naukowej formule oraz w szerszej perspektywie postanowił przedstawić również Jan Olaszek, wśród młodego pokolenia historyków jeden z najwybitniejszych znawców tematu․ Jako autor książki Rewolucja powielaczy. Niezależny ruch wydawniczy w Polsce 1976-1989 został w maju 2016 r. laureatem Nagrody Historycznej „Polityki”. Jego pracę rzeczywiście jest za co pochwalić - nie można się jednak po jej lekturze oprzeć wrażeniu sporego niedosytu.

Układ treści w Rewolucji powielaczy jest chronologiczny. Olaszek rozpoczyna swój wywód od pieczołowitej rekonstrukcji działań studentów Katolickiego Uniwersytetu Lubelskiego, zainspirowanych wykładami o polskim państwie podziemnym, którzy w połowie lat 70. zapragnęli przeciwstawić się systemowi PRL-owskiemu i naruszyć informacyjny monopol Polskiej Zjednoczonej Partii Robotniczej. Ukazuje, jak weszli oni w posiadanie

\footnotetext{
1 We wrześniu 2016 r. ukazała się również współredagowana przez niego imponująca praca zbiorowa Drugi obieg w PRL na tle samizdatu w państwach bloku sowieckiego po 1956 roku, red. P. Gasztold-Seń, N. Jarska, J. Olaszek, Instytut Pamięci Narodowej, Warszawa 2016.
} 
przemyconego z Londynu powielacza i jak nawiązali współpracę z warszawskimi dysydentami skupionym w Komitecie Obrony Robotników, szukającymi sposobów na rozpowszechnienie informacji o swoich działaniach, opisywanych w „Komunikacie” i „Biuletynie Informacyjnym”. Dokładnie przedstawia okoliczności powstania pierwszego niezależnego pisma wykraczającego poza „bieżączkę”, czyli literackiego „Zapisu”, oraz procesów, które doprowadziły do powstania latem 1977 r. Niezależnej Oficyny Wydawniczej NOWA. Dalsze fragmenty przybliżaja czytelnikowi profil ideowy i zawartość kolejnych bezdebitowych tytułów prasowych wydawanych przez różne środowiska: „Głosu”, „Robotnika” (w tym przypadku również jego znaczenie dla powstania i działalności Wolnych Związków Zawodowych), „Opinii”, „Pulsu” czy „Bratniaka”. Znaleźć tam można również informacje o ważnych dyskusjach ideowych (takich jak spór wokół eseju Piotra Wierzbickiego Traktat o gnidach) albo znaczących wydarzeniach, takich jakich głodówka w obronie aresztowanych Mirosława Chojeckiego i Bogdana Grzesiaka.

Dalsze rozdziały przypominaja, jak ogromną rolę odegrała poligrafia kierowana zreszta przez doświadczonych działaczy drugiego obiegu - podczas strajków w sierpniu 1980 r. Olaszek opisuje powstanie „Strajkowego Biuletynu Informacyjnego Solidarność”, rozprowadzonego po całym kraju i rozbijającego informacyjna blokadę wprowadzona przez władze. Autor poświęca również bardzo dużo miejsca opisowi zmiany, jaką przyniosło powstanie „Solidarności”: rozkwit wydawnictw związkowych w całej Polsce i umasowienie bibuły, która nagle stała się dostępna niemal oficjalnie. Przywołuje również dylematy tego czasu: pytania o to, czy kontynuować dotychczasowe inicjatywy (takie jak Niezależna Oficyna Wydawnicza), współpracując z „Solidarnością, ale zachowując własną, niezależną markę - czy może wchodzić całkowicie w nurt działań związkowych?

Kolejna część książki roztacza panoramę inicjatyw opozycyjnych rodzących się po otrząśnięciu się z szoku stanu wojennego. Olaszek przypomina o błyskawicznym tempie, w jakim już w grudniu 1981 r. odrodziła się „bibuła”, by następnie przedstawić najważniejsze środowiska solidarnościowej konspiry: „Tygodnik Mazowsze” i „Tygodnik Wojenny”, pisma literackie i - szerzej - kulturalne, czy wreszcie tytuły związane z zakładami pracy i podziemnymi strukturami związkowymi. Ostatni rozdział z kolei oddaje atmosferę demobilizacji, która zapanowała w łonie opozycji około roku 1986: wypalenie się emocji, zniechęcenie, poczucie pogłębiającej się rutynizacji i kontestacji. Wzmiankuje o zmianach na podziemnym rynku, na którym klient stawał się coraz bardziej wybredny, oraz równoległym do

\section{/ 312 STANRZECZY 2[11]/2016}


wyżej wymienionych przemian procesie instytucjonalizacji, by wymienić choćby powstanie Funduszu Wydawnictw Niezależnych. Pokazuje wreszcie zmiany na linii władza-opozycja, których rezultatem było m.in. wyjście na powierzchnię redakcji „Res Publiki” czy rozłam w Niezależnej Oficynie Wydawniczej, której część działaczy postanowiła założyć własne, ale już legalne wydawnictwo.

Naszkicowany powyżej wywód autora jest spójny, uporządkowany i nasycony bardzo dużą ilością informacji. Tym samym Rewolucja powielaczy pozwala na urzeczywistnienie celu, jaki na wstępie postawił sobie Olaszek: ukazania fenomenu niezależnego ruchu wydawniczego w sposób, który byłby atrakcyjny dla czytelnika w bardzo niewielkim stopniu zaznajomionego z tematem. $\mathrm{Na}$ tym polu historyk odniósł bardzo duży sukces. Napisał bowiem przystępną, nieprzeciążoną żargonem akademickim pracę, która pozwala zrozumieć, jak ważnym, a właściwie kluczowym, elementem kontestacji monopolistycznej władzy PZPR był niezależny ruch wydawniczy. Jest to również wyraźna i obszerna mapa jego wewnętrznego zróżnicowania, ukazująca bogactwo inicjatyw i środowisk, które się na niego składało. Przypominając o konkretnych inicjatywach, takich jak chociażby „Głos”, „Tygodnik Mazowsze” lub „Przegląd Wiadomości Agencyjnych” - bądź o oficynach książkowych takich jak NOWA lub Krąg - Olaszek doskonale oddaje specyfikę każdej z nich - profil ideowy, rodzaj publikowanych materiałów, najważniejsze artykuły bądź dyskusje, „target” czytelniczy etc. Autor nie zapomina o publikacjach „Solidarności Walczącej”, pismach adresowanych do żołnierzy czy milicjantów, gazetach dla uczniów czy wreszcie tytułach satyrycznych (aczkolwiek szkoda, że nie wspomina o rozkwitających w latach 80. wydawnictwach takich jak fanziny punkowe czy pisma środowisk kontestatorskich krytycznych wobec „solidarnościowej" opozycji - np. anarchistów). Ogromną wartością Rewolucji powielaczy jest tym samym uzmysłowienie, że opór przeciw opresyjnemu systemowi realizował się w ogromnej mierze nie poprzez zbiorowe i gwałtowne uniesienia, lecz przez codzienna, często żmudną pracę.

Niestety, ta sumienność autora okazuje się w pewnym momencie w dużym stopniu jednowymiarowa. Rewolucja powielaczy tylko w delikatny sposób dotyka całej niezwykle bogatej rzeczywistości poza redakcjami podziemnych czasopism i oficyn, plątaniny działań, które prowadziły od decyzji wydawniczej do przekazania gotowych egzemplarzy w ręce czytelników. W niektórych fragmentach książka Olaszka zamienia się w - rozbudowany co prawda - spis tytułów prasowych i środowisk, z którymi były one zwią- 
zane. Szczególnie silnie doskwierające wrażenie sprawia rozdział poświęcony konspiracji stanu wojennego, najbardziej upodabniający się do leksykonu kolejnych inicjatyw. Brakuje natomiast przybliżenia, czym się różniły i jak działały powielacz spirytusowy, białkowy i offsetowy; brakuje również opowieści o tym, jak zdobywało się lub produkowało matryce lub farbę drukarską, a także o tym, w jakie miejsca trzeba się było udać, by uzyskać większą partię papieru (co, z uwagi na braki rynkowe, nie było zadaniem łatwym). Olaszek właściwie w ogóle nie zagląda też do podziemnych drukarni. Prawie nieobecna w jego książce jest wiedza o tym, gdzie znajdowały się takie lokale, w jaki sposób je urządzano, co robiono, by dotrzeć do nich, minimalizując ryzyko przyciagnięcia esbeckiego ogona.

Nie dowiadujemy się również, jak i gdzie składane były publikacje, jak tkano sieci ich kolportażu. Doskwiera nieobecność opisu, w jaki sposób była zorganizowana sprzedaż, która przybierała również różnorodne formy: od wizyt kolporterów w zakładach przemysłowych czy instytucjach naukowych przez wykładanie egzemplarzy w opozycyjnym salonie Tadeusza i Anny Walendowskich po funkcjonowanie (w okresie korowskim) półjawnych „sklepików” z bibułą u Ewy Milewicz czy Mieczysława Grudzińskiego. Szkoda też, że Olaszek nie pokusił się o zarysowanie przestrzeni, którą Paweł Sowiński określił mianem „otoczenia ruchu społecznego”, a na którą składały się postawy i działania tych, którzy aktywnie i regularnie nie konspirowali, ale byli gotowi stworzyć wokół dysydentów przyjazna atmosferę lub np. dezinformować poszukujących jakiegoś adresu esbeków (Sowiński 2016). Żałować można również nieobecności w jego wywodzie innego typu peryferii drugiego obiegu, jakie stanowiły przykładowo legalne zakłady poligraficzne, których pracownicy drukowali - „po godzinach” i za opłata - na potrzeby opozycji.

Co więcej, czytelnik nie dowie się też wiele o samych „pełnoetatowych” podziemnych drukarzach - zresztą, nie tylko o nich, gdyż pod tytułami pism i książek gina jakoś portrety wszystkich osób, które umożliwiły ich powstanie oraz funkcjonowanie. Jak to się działo, że w drugim obiegu spotkali się Jan Walc - pracownik Instytutu Badań Literackich PAN, autor subtelnych esejów - oraz Roman „Romaszko” Wojciechowski, wytatuowany alkoholik z więzienna przeszłością, a przy tym doskonały i ofiarny drukarz. Co do Niezależnej Oficyny Wydawniczej wnosili intelektualiści lub zawodowi redaktorzy - co zaś robotnicy, tacy jak Emil Broniarek, kolportujący jej wydawnictwa w zakładach w Ursusie? Jak wzajemnie postrzegali się inteligenci i proletariusze? Czy wspólne knucie przełamywało bariery, również klasowe, czy raczej pozostawało różne światy w rozdzieleniu? Jak 
wyglądało życie towarzyskie tego środowiska - naświetlenie tego byłoby ważne nie tyle z powodów plotkarskich, lecz dla uchwycenia wspólnototwórczego charakteru aktywności drugoobiegowej, której etos miał wiele wspólnego nie tylko z ideą bądź programami politycznymi, lecz także z osobistą lojalnością i zaufaniem, tworzeniem, jak to wyraził Tomasz Jastrun, w latach 70. wspólpracownik Niezależnej Oficyny Wydawniczej NOWA, „mapy ciepłych miejsc”, rozsianych po całej Warszawie (Bertram 2013: 75-76).

Cała ta warstwa jest w Rewolucji powielaczy sprowadzona de facto do jednego niewielkiego podrozdziału na końcu książki oraz do rozsianych po niej krótkich wzmianek. Są to np. - przywoływane już w literaturze - anegdoty o innowacyjnym zastosowaniu gumy od majtek przy powielaniu na „ramce” (prostym, ręcznie napędzanym urządzeniu drukarskim) bądź pasty do prania „Komfort”. Równie zdawkowe są fragmenty dotyczące działań władz i Służby Bezpieczeństwa wobec drugiego obiegu. Z uznaniem należy przyjąć, że autor zapoznał czytelnika z działalnościa Pawła Mikłasza, kierownika technicznego Wydawnictwa im. Konstytucji 3 Maja, a jednocześnie wieloletniego tajnego współpracownika bezpieki - oraz z niewiarygodną historią Mariana Pękalskiego, oficera kontrwywiadu, który pod zmyślonym nazwiskiem Romana Kotarskiego przeniknął w stanie wojennym do podziemia i został szefem Wydawnictwa Rytm². Historyk nie naszkicował jednak ogólnej logiki postępowania kierownictwa partyjnego oraz MSW - od samego początku istnienia drugiego obiegu niekonsekwentnej, meandrującej, zależnej od układu sił pomiędzy czynnikami dążącymi do większej represyjności a tymi, które zbyt ostrą politykę powstrzymywały (Friszke 2008: 15-16). Olaszek słusznie przywołuje też jeden z bardziej dramatycznych epizodów w dziejach drugiego obiegu losy braci Andrzeja i Janusza Górskich, z których pierwszy był jednym z najbardziej ofiarnych drukarzy NOWEJ, drugi zaś - wieloletnim wspó1pracownikiem Służby Bezpieczeństwa (zob. Sowiński 2013). W relacjach i dokumentach związanych z tą historia jak w soczewce skupia się bardzo dużo istotnych wątków: codzienność pracy jednej z grup drukarskich, metody konspiry, kontakty i obieg informacji między drukarzami a szefami podziemia, figura zdrajcy i bohatera, sposoby inwigilacji i rozpracowywania konspiratorów, a wreszcie - wysoka cena, z jaką nierzadko wiązało się zaangażowanie w opozycję. Dzieje braci Górskich nadawałyby się idealnie, by w Rewolucji powielaçy służyć jako swoiste pars pro toto doświadczenia

2 Prawdziwa tożsamość Pękalskiego/Kotarskiego ujawniona została dopiero w 2012 roku. 
drugiego obiegu, szczególnie okresu 1982-1986. Ten potencjał pozostał w książce Olaszka mocno niewyzyskany.

Z uwagi na przywołane wyżej walory popularyzatorskie trudno mieć do autora pretensje o to, że nie próbował przyłożyć do rzeczywistości drugoobiegowej ram teoretycznych - takich jak koncepcja ruchu społecznego lub propozycja Tadeusza Szawiela postrzegania środowisk opozycyjnych jako grup ethosowych (2011). Można jedynie żałować, że nie wykorzystał tropów proponowanych przez Mateusza Fałkowskiego, interpretującego inicjatywy drugoobiegowe w kategoriach przedsiębiorstw działających na pewnym rynku $(2011,2016)$. Trudniej zaakceptować, że spojrzenie Jana Olaszka na historię niezależnego ruchu wydawniczego jest przede wszystkim tożsame z perspektywą inteligenta, redaktora bezdebitowej prasy lub kierownika takiej oficyny. Nie oznacza to w żadnym wypadku, iż jest to rzeczywistość, którą należy w badaniach i refleksjach pomijać. Rewolucja powielac $y$ to doskonały przewodnik po polskiej opozycji demokratycznej, dzięki któremu odbiorca rozpoczynający swoją przygodę z jej historią będzie wiedział, czym była i jakie znaczenie miała Niezależna Oficyna Wydawnicza lub „Komunikat” KOR albo w jaki sposób rzeczywistość po 13 grudnia interpretowała redakcja „Tygodnika Wojennego”. Jeśli jednak autor postawił sobie ambitny cel nie przedstawienia pewnego wycinka, lecz ujęcia fenomenu drugiego obiegu w całościowy sposób, w tej wizji nie może zabraknąć - mówiąc obrazowo - ukazania garaży i piwnic, miejsc przechowywania paczek z gazetami, których treść tak wnikliwie analizuje autor Rewolucji powielac $y$.

Nie chodzi tu o detale dla samych detali. Życie w konspiracyjnym zanurzeniu, dysydenckiej jawności lub w strefie pośredniej obfitowało w wydarzenia zarówno komiczne, jak i tragiczne. Pozwalało na tworzenie wspólnoty przekraczającej wszelkie możliwe granice, integrowało wysublimowanych intelektualistów lub osoby z „dobrych domów” z robotnikami (czego wyrazistym przykładem jest przyjaźn dwóch ludzi NOWEJ - Macieja Radziwiłła i Andrzeja Górskiego). Jednocześnie zaangażowanie w ruch sprowadzało na jego uczestników rodzinne dramaty, niszczyło „normalną” egzystencję, przyzwyczajało do wiecznej walki, z której ciężko było niektórym zrezygnować po przełomie 1989 r., rodziło zaciekłe konflikty. Te ciemne strony „knucia” - alkoholizm, rozbite rodziny, wieloletnia zapiekłość między niegdyś bliskimi sobie ludźmi - są szczególnie widoczne we wspomnianym na wstępie reportażu Jacka Hugo-Badera, gdzie prawie nic nie mówi się o treściach, za powielanie których bohaterowie książki ryzykowali zdrowie i wolność. U Olaszka z kolei jest odwrotnie - to, co i pod 
jakimi szyldami drukowano, przysłania bogactwo relacji między uczestnikami drugiego obiegu oraz środki, dzięki którym było to w ogóle możliwe. Lekturze jego pracy towarzyszy zatem dźwięk szeleszczącego papieru, słabo jednak słychać hałas kręcącego się powielacza.

Bibliografia:

/// Bertram L., oprac. 2013. Obieg NOW-ej, Instytut Pamięci Narodowej.

/// Gasztold-Seń P., Jarska N., Olaszek J., red. 2016. Drugi obieg w PRL na tle samizdatu w państwach bloku sowieckiego po 1956 roku, Instytut Pamięci Narodowej.

/// Fałkowski M. 2011. Biænes patriotyczny. Historia wydawnictwa CDN, Europejskie Centrum Solidarności.

/// Fałkowski M. 2016. Ruch społeczny i „podziemny rynek”. O logikach funkcjonowania niezależnego ruchu wydawniczego w PRL (1976-1989), [w:] Drugi obieg w PRL na tle samizdatu w panstwach bloku sowieckiego po 1956 roku, Instytut Pamięci Narodowej, s. 76-101.

/// Friszke A., Zaremba M. oprac. 2008. Rozmowy na Zawracie. Taktyka walki z. opozycja demokratyczna, październik 1976 - grudzień 1979, Instytut Studiów Politycznych PAN.

/// Hugo-Bader J. 2016. Skucha, Agora, Wydawnictwo Czarne.

/// Olaszek J. 2015. Rewolucja powielaczy. Niezależny ruch wydawniczy w Polsce 1976-1989, Trzecia Strona.

/// Sowiński P. 2013. Biograficzne konsekwencje ruchu spotecznego: præypadek braci Andræeja Janusza Górskich, „Working Papers on the Solidarity Movement”, nr 8 .

/// Sowiński P. 2016. Drugi obieg wydawniczy - otoczenie ruchu spotecznego, [w:] Drugi obieg w PRL na tle samizdatu w panstwach bloku sowieckiego po 1956 roku, Instytut Pamięci Narodowej, s. 102-122.

/// Szawiel T. 2011. Struktura społeczna i postawy a grupy ethosowe. (O możliwościach ewolucji społecznej), „Studia Socjologiczne”, nr 1, s. 279-297. 